\title{
Different energy sources for three symbiont-dependent bivalve molluscs at the Logatchev hydrothermal site (Mid-Atlantic Ridge)
}

\author{
Eve G. Southward*, Andrey Gebruk ${ }^{\dagger}$, Hilary Kennedy ${ }^{\ddagger}$, Alan J. Southward* \\ and Pierre Chevaldonné ${ }^{\jmath}$ \\ *Marine Biological Association, The Laboratory, Citadel Hill, Plymouth, PL1 2PB. ${ }^{\dagger}$ P.P. Shirshov Institute of Oceanology, Russian \\ Academy of Sciences, Nakhimovsky Pr. 36, Moscow, 117851, Russia. ${ }^{\ddagger}$ School of Ocean Sciences, University of Wales, Bangor, Menai \\ Bridge, Anglesey, LL59 5EY. `UMR DIMAR, Centre d'Océanologie de Marseille, Station Marine d'Endoume, \\ Rue de la Batterie des Lions, 13007 Marseille, France.*E-mail 100721.3720@compuserve.com
}

\begin{abstract}
The vent mussel Bathymodiolus puteoserpentis, a large vesicomyid clam and a smaller thyasirid were collected from an area of sediment subject to diffuse hydrothermal flow. The mussels live on the surface, the vesicomyids are partly buried and the thyasirids burrow in the sediment. The fine structure of the gills differs in the three bivalves. Bathymodiolus puteoserpentis hosts two types of bacterial symbiont, one methanotrophic, and another probably thiotrophic. The other two bivalves have single types of symbiont of different shapes. Stable isotope ratios of carbon and nitrogen indicate thiotrophy in the vesicomyid and thyasirid, but a predominance of methanotrophy in the mussel. This is the first time that such an assemblage has been found at a hydrothermal site on the Mid-Atlantic Ridge (MAR), with the different faunistic elements exploiting different energy resources.
\end{abstract}

\section{INTRODUCTION}

Since discovery in 1986, the hydrothermal vents at the MAR have become famous for the presence of large swarms of bresilioid shrimps (Rona et al., 1986). However, other locally abundant animals at the MAR vents include symbiotrophic mussels of the genus Bathymodiolus (Segonzac, 1992; Cosel et al., 1994, 1999; Craddock et al., 1995; Maas et al., 1999). Starting at the north end of the chain of inhabited vent sites along the MAR, Bathymodiolus azoricus occurs at Menez Gwen $\left(37^{\circ} 50^{\prime} \mathrm{N}\right)$, Lucky Strike $\left(37^{\circ} 17^{\prime} \mathrm{N}\right)$ and Rainbow $\left(36^{\circ} 14^{\prime} \mathrm{N}\right)$. There may be an overlap of mussel species (Jollivet et al., $1998)$ at Broken Spur $\left(29^{\circ} 10^{\prime} \mathrm{N}\right)$, but mussels are rare there and are virtually absent at TAG $\left(26^{\circ} 08^{\prime} \mathrm{N}\right)$. A second species of mussel, Bathymodiolus puteoserpentis, is common at Snake Pit $\left(23^{\circ} 22^{\prime} \mathrm{N}\right)$ and extends southwards to Logatchev $\left(14^{\circ} 45^{\prime} \mathrm{N}\right)$. In 1997 three of the authors (ECS, AG and PG) took part in a cruise of RV 'Atlantis' (MAR '97) that visited all these sites, using the submersible 'Alvin'. Logatchev is the southernmost hydrothermal site so far investigated on the MAR, and the only one with a substantial area of soft sediment. At Logatchev mussels were found on three major vent fields, the Main Mound, the 'Irina 2' chimney complex and the sedimented area named 'Anya's Garden' (Gebruk et al., 2000a). The latter was found to have a population of large vesicomyid clams and two species of Thyasiridae, in addition to the mussels (Bathymodiolus puteoserpentis). This was the first time live vesicomyids were reported from the MAR.

In the course of an investigation of the diet of vent shrimps (Gebruk et al., 2000b), various food items that might be used by the shrimp were sampled, including specimens of three species of bivalve from 'Anya's Garden', for stable isotope ratios of carbon and nitrogen. Microscopic examination of the gills of these bivalves revealed interesting differences in fine structure of their bacteriocytes and symbionts which, taken with differences in the stable isotope ratios, indicated that a variety of energy sources were utilized in the symbioses.

\section{MATERIALS AND METHODS}

The bivalves were collected at the Logatchev vent field on the MAR during cruise 3, leg 3 of RV 'Atlantis'. They were sampled on dive 3133 of the DSRV 'Alvin' at $3038 \mathrm{~m}$, $14^{\circ} 45.189^{\prime} \mathrm{N}$; $44^{\circ} 58.829^{\prime} \mathrm{W}$; 27 July 1997 . The observers were R.A. Lutz and Michelle Bunzel. Vesicomyids, mussels and a few thyasirids were sampled with a scoop, using the remote arm of 'Alvin', in the area known as 'Anya's Garden'. Video recordings of this area made during dive 3133 show habitat details. Most of the mussels and vesicomyid clams were used for meristic and genetic studies (e.g. Maas et al., 1999). In the ship's laboratory, parts of the gills were removed from one of each type of bivalve and small pieces were fixed for electron microscopy, other parts of the gill and part of the foot were dried separately at $60^{\circ} \mathrm{C}$. The other tissues and shell were preserved in $4 \%$ formaldehyde/seawater.

The fixation for electron microscopy was undertaken onboard ship, using $0.1 \mathrm{M}$ cacodylate-buffered 2.5\% glutaraldehyde, with $4 \mathrm{M}$ sucrose ( $\mathrm{pH} 7.4,2 \mathrm{~h}$, ice cold, dark). Material was then rinsed four times in $0.1 \mathrm{M}$ buffer with decreasing sucrose molarity, from 3 to $0 \mathrm{M}$ (each rinse $10 \mathrm{~min}$, ice cold, dark). Tissues were post-fixed in 
$0.1 \mathrm{M}$ cacodylate-buffered $1 \%$ osmium tetroxide for $1 \mathrm{~h}$ in the dark, on ice. After two rinses in cacodylate buffer, tissues were dehydrated in three ethanol steps to $70 \%$. At Plymouth the material was further dehydrated in ethanol series to $100 \%$, embedded in Spurr resin and sections cut on a Reichert microtome. Thin sections were mounted on grids, and stained with uranyl acetate and lead citrate. Semi-thin sections were mounted on slides and stained with toluidine blue.

For stable isotope analysis, the dried samples were homogenized and subsamples loaded into precombusted silver boats $\left(500^{\circ} \mathrm{C}, 3 \mathrm{~h}\right)$, acidified $(2 \mathrm{~N} \mathrm{HCl})$ and dried. Copper and precombusted copper oxide $\left(910^{\circ} \mathrm{C}\right)$ were added to the boats, which were then loaded into precombusted quartz tubes and sealed under vacuum. These tubes were combusted at $910^{\circ} \mathrm{C}$ for $3 \mathrm{~h}$ and allowed to cool slowly overnight. The resulting $\mathrm{CO}_{2}$ and $\mathrm{N}_{2}$ were separated cryogenically. The $\mathrm{N}_{2}$ was analysed on a VG SIRA II and $\mathrm{CO}_{2}$ on a PDZ-EUROPA mass spectrometer. Results are expressed relative to $\mathrm{PDB}$ and atmospheric nitrogen standards in the usual notation. Precision of an internal laboratory sub-standard was $0.05 \%$.

Total carbon and nitrogen in the powdered dried tissues were analysed by R.N. Head, Plymouth Marine Laboratory. Total sulphur was measured by Elemental Microanalysis Ltd, Okehampton, Devon.

\section{RESULTS}

\section{Habitat}

'Anya's Garden' is in the north-western part of the Logatchev site (Gebruk et al., 2000a, Figure 1), at $\sim 3040 \mathrm{~m}$ depth. The clam field was at least $12 \mathrm{~m}$ across, on soft sediment (Gebruk et al., 2000a, Figure 3). Most of the clams were partly buried, in the inclined position typical of vesicomyids. Their distribution was very uneven, varying from small groups of three or four individuals to aggregations covering several $\mathrm{m}^{2}$ with a density of $<100 \mathrm{~m}^{-2}$. One of the aggregations formed a small bank $0.4 \mathrm{~m}$ high and $8 \mathrm{~m}$ long, presumably following a pattern of fluid discharge from within the sediment. Mussels were present on the surface in clusters of 4-60 individuals, often associated with visible diffuse fluid flow. Clams and mussels were rarely seen together. Thyasirids $<18 \mathrm{~mm}$ in diameter occurred in sediment among the clams. The thyasirid shells visible on the surface reached a density of $20 \mathrm{~m}^{-2}$. A temperature of $7^{\circ} \mathrm{C}$ was measured in diffuse flow immediately above one of the mussel clusters. The ambient bottom temperature was $2.8^{\circ} \mathrm{C}$.

Fine structure of gills and symbionts Family MYTILIDAE

Bathymodiolus sp. aff. puteoserpentis Cosel, Comtet, and Krylova, 1999; cf. Bathymodiolus puteoserpentis Cosel,

Metivier and Hashimoto, 1994

The common vent mussel at Logatchev (Figure 1A) differs in some subtle morphological characters (particularly the coiling of the intestine) from Bathymodiolus puteoserpentis at the type locality (Snake Pit), but Maas et al. (1999), using allozymes, found no substantial genetic
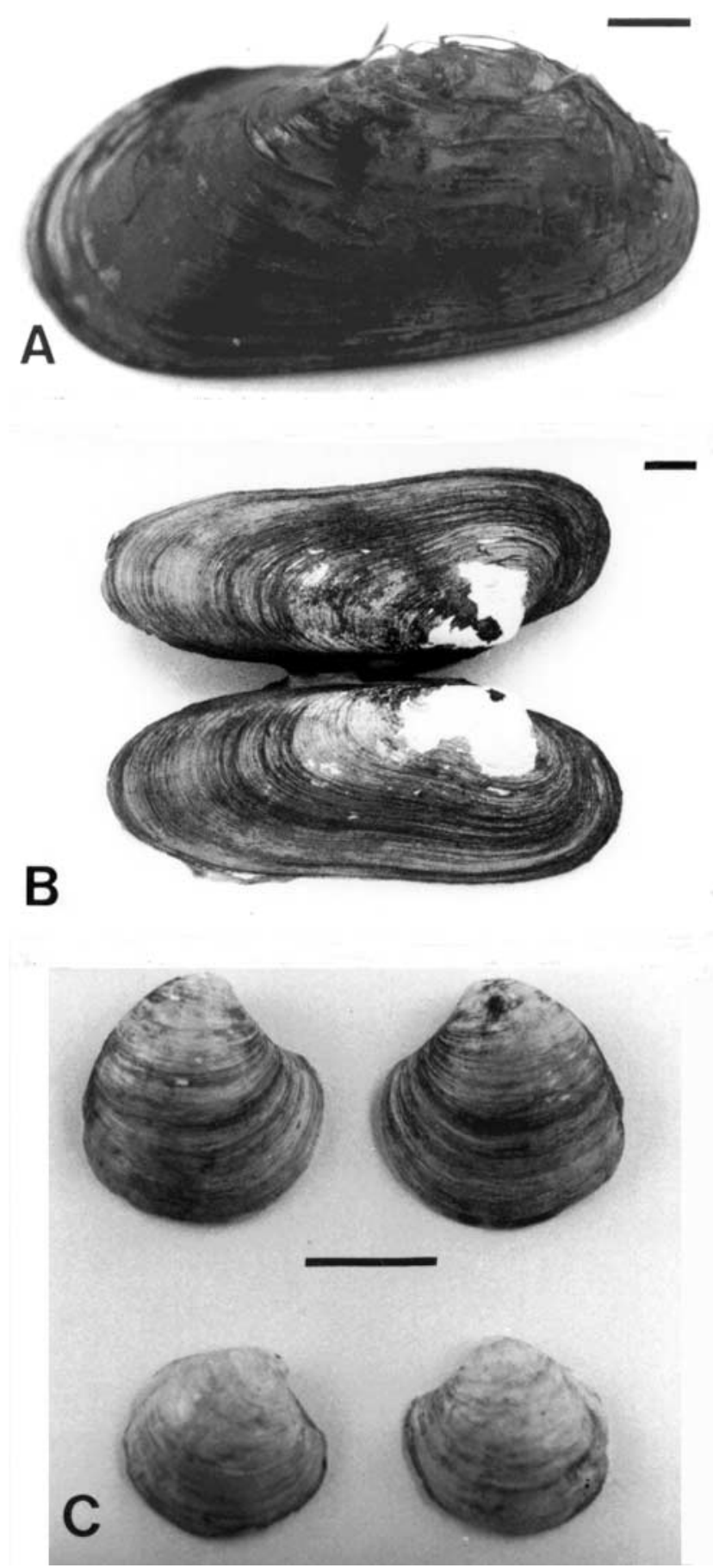

Figure 1. Shells of Logatchev bivalves. (A) Bathymodiolus puteoserpentis; (B) Calyptogena (Ectenagena) sp.; (C) Thyasira spp. Scale bars: $10 \mathrm{~mm}$.

divergence between the Snake Pit and Logatchev populations.

A specimen 53-mm long was examined for symbionts. Each ctenidium has two thick demibranchs. Their descending and ascending lamellae are made up of ribbon-shaped filaments about $1 \mathrm{~mm}$ deep and $<100 \mu \mathrm{m}$ thick. The frontal region of each filament has typical mytilid ciliation. A single series of ciliary junctions is present each side of the filament, spaced at intervals of $\sim 0.3 \mathrm{~mm}$. The general morphology of the gills is very similar to that described by Le Pennec \& Hily (1984) for Bathymodiolus thermophilus from the East Pacific Rise vents, 

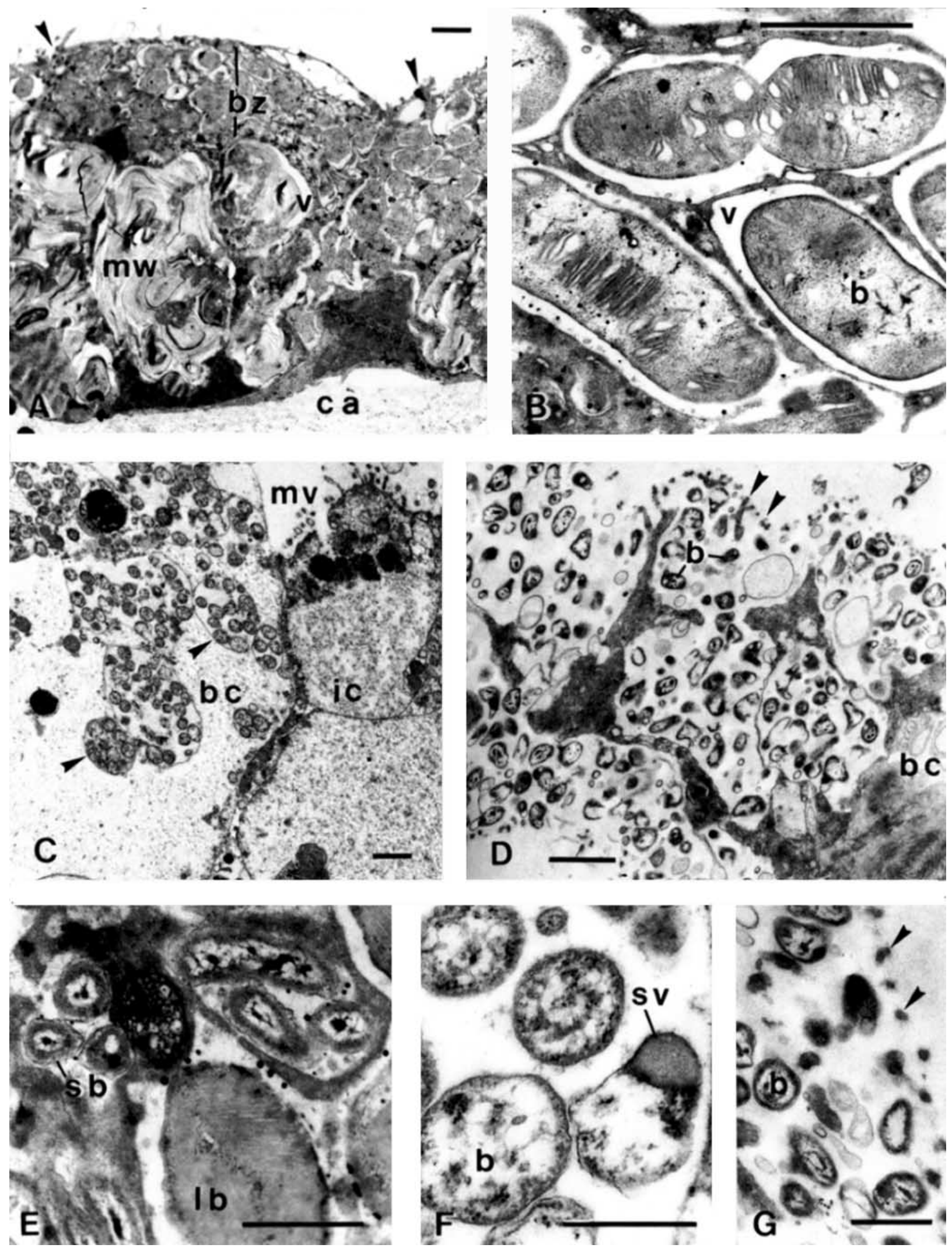

Figure 2. Sections of gill filaments of Logatchev bivalves, transmission electron micrographs. (A) Bathymodiolus puteoserpentis, bacteriocyte and intercalary cells (arrows); (B) B. puteoserpentis, large bacteria with stacks of membranes; $(\mathrm{C})$ Calyptogena (Ectenagena) sp., bacteriocyte with vacuoles full of bacteria (arrows), and intercalary cell; (D) Thyasira sp., surface of bacteriocyte with long branched microvilli and bacteria under layer of tips of microvilli (arrows); (E) B. puteoserpentis, small bacteria and large bacteria in separate vacuoles; (F) Calyptogena, bacteria, with sulphur vesicle; (G) Thyasira, tips of microvilli (arrows), forming a layer covering bacteria. b, bacterium; bc, bacteriocyte; bz, bacterial zone; ca, collagenous axis; ic, intercalary cell; lb, large bacterium; mv, microvillus; mw, membranous whorls in vacuole; sb, small bacteria; sv, sulphur vesicle; v, vacuole. Scale bars: $\mathrm{A}-\mathrm{D}, 1 \mu \mathrm{m} ; \mathrm{E}-\mathrm{G}, 0.5 \mu \mathrm{m}$. 
except that the latter has four series of ciliary junctions each side of the filament.

The abfrontal surfaces of the filaments are covered by a pavement epithelium formed of large, smooth-surfaced bacteriocytes and very small intercalary cells (Figure 2A). The apical $5-6 \mu \mathrm{m}$ of the bacteriocyte cytoplasm is crowded with bacteria-filled vacuoles. The basal regions of the cells contain the nucleus and many large vacuoles holding the sparse membranous remains of lysed bacteria. The intercalary cells have a microvillar surface with occasional short cilia. Their nuclei are in the apical region.

Two types of bacteria are present. The large type is $\sim 1.5-3 \mu \mathrm{m}$ long $\times 0.6-1.0 \mu \mathrm{m}$ diameter, or almost spherical and $\sim 1.4 \mu \mathrm{m}$ in diameter. They contain stacks of intracytoplasmic membranes, typical of type I methanotrophs, and usually occur singly, but there may be two or three per vacuole (Figure 2B).

Small rod-shaped bacteria are usually in separate vacuoles, singly or in small groups (Figure 2E). They are less than $1 \mu \mathrm{m}$ long and $0.10-0.15 \mu \mathrm{m}$ in diameter. One end is sometimes swollen to as much as $0.25 \mu \mathrm{m}$ in diameter. There are no obvious intracytoplasmic membranes or vacuoles.

Counts on electron micrographs show that the two types of bacteria occur in approximately equal numbers in a thin section, but the difference in their sizes means that the large oval methanotrophs occupy about a hundred times the volume occupied by the small rods. Both types of bacteria are present in the large phagocytic vacuoles in the basal part of the bacteriocyte.

\section{Family VESICOMYIDAE \\ Calyptogena (Ectenagena) sp. (Figure 1B)}

This species appears to be more closely related, both morphologically (E. Krylova, personal communication) and genetically (R.C. Vrijenhoek, personal communication) to C. kaikoi from Japan than to vesicomyids known from the western Atlantic.

The specimen examined was $100 \mathrm{~mm}$ long. The bulky ctenidia were reddish brown in life, with cream-coloured patches. Each is a single demibranch, with descending and ascending lamellae. Within the gill lamella the filaments are modified to form rows of cylinders arranged so that water can flow through their bacteriocyte-lined lumina. The basement laminae of the cylinders are enveloped in a system of blood-filled spaces. The bacteriocytes are accompanied by small intercalary cells, which have a microvillar outer surface (Figure 2G). The bacteriocytes themselves have basal nuclei and uniformly granular cytoplasm. Small and large vacuoles, full of bacteria, are abundant in the apical part of each cell. Among them are a few small vacuoles, with electron-dense contents, while in the basal part of the cell there are large vacuoles holding less dense 'waste' granules that appear brown under the light microscope. Rounded spaces in the basal part of the bacteriocyte are filled with a uniform moderately electron-dense material surrounded by cytoplasmic membrane and an extracellular lining. It is possible that the material is blood and the spaces are extensions of the intercylindrical blood spaces.

The bacteria are $\sim 0.4-0.6 \mu \mathrm{m}$ in diameter and coccoid in shape, with occasional intracytoplasmic vesicles (Figure 2F) resembling the sulphur vesicles found in typical sulphur-oxidizing bacteria (Southward, 1986). They do not contain stacked membranes. They resemble the symbionts of other vesicomyids, which utilize sulphur-oxidation as an energy source (Tuttle, 1985; Fiala-Médioni \& Métivier, 1986; Fiala-Médioni \& Le Pennec, 1988).

\section{Family THYASIRIDAE Thyasira (Parathyasira) sp. (Figure 1C)}

Two species were present in the sample (E. Krylova, personal communication) but only one specimen was fixed and examined for gill bacteria. It was already damaged and the gills had deteriorated. The microscopic anatomy of the gill filaments is similar to that of Thyasira flexuosa and T. sarsi (Southward, 1986), with abundant bacteria held in superficial blister-like structures, supported by long microvilli and covered by the tips of the microvilli (Figure 2D \& G). The bacteria are all short rods, $0.3-0.6 \mu \mathrm{m}$ long $\times 0.1-0.4 \mu \mathrm{m}$ diameter. They contain occasional intracytoplasmic vesicles, resembling sulphur vesicles (cf. Southward, 1986, Figure 4B).

\section{Stable isotopes of carbon and nitrogen}

The results of the analyses are set out in Table 1 . There is a marked difference in $\delta^{13} \mathrm{C}$ value between Bathymodiolus puteoserpentis and the other two bivalves. The highly depleted values for the vesicomyid and thyasirid are in line with data for other bivalves with thiotrophic symbionts using ambient $\mathrm{CO}_{2}$ as their carbon source. The value for $B$. puteoserpentis indicates a different carbon source, presumed to be methane of abiogenic origin (see Lein \& Sagalevich, 2000). For Thyasira the $\delta^{15} \mathrm{~N}$ indicates a more reduced nitrogen source than in the other bivalves.

Table 1. Stable isotope ratios in Logatchev bivalves.

\begin{tabular}{llcr}
\hline Species & Tissue & $\delta^{13} \mathrm{C}(\% \mathbf{0})$ & $\delta^{15} \mathrm{~N}(\% \mathbf{0})$ \\
\hline Thyasirid & Gill & -34.03 & -3.83 \\
Vesicomyid & Gill & -36.27 & 1.53 \\
Vesicomyid & Foot & -34.79 & 3.64 \\
Bathymodiolus puteoserpentis & Gill & $-14.30,-14.41^{*}$ & $1.43,1.61^{*}$ \\
Bathymodiolus puteoserpentis & Foot & $-14.86,-14.83^{*}$ & $1.87,1.86^{*}$ \\
\hline
\end{tabular}

*, duplicate subsamples. 
Table 2. Range of stable isotope ratios for Mid-Atlantic Ridge mussels from sites other than Logatchev.

\begin{tabular}{|c|c|c|c|c|c|}
\hline Species & Site & Tissue & $\delta^{13} \mathrm{C}(\%)$ & $\delta^{15} \mathrm{~N}(\% \mathbf{0})$ & Reference \\
\hline $\begin{array}{l}\text { Bathymodiolus } \\
\text { puteoserpentis }\end{array}$ & Snake Pit & $\begin{array}{l}\text { Gill } \\
\text { Foot }\end{array}$ & $\begin{array}{l}-36.8--37.6 \\
-34.2--34.9\end{array}$ & $\begin{array}{l}-15.6--19.3 \\
-14.8--15.2\end{array}$ & $\begin{array}{l}\text { Robinson et al., } 1998 \\
\text { Robinson et al., } 1998\end{array}$ \\
\hline \multirow{5}{*}{$\begin{array}{l}\text { Bathymodiolus } \\
\text { azoricus }\end{array}$} & Lucky Strike & & & & \\
\hline & Sintra vent & Gill & $-14.7--25.1$ & $0--8.8$ & Trask \& Van Dover, 1999 \\
\hline & & Mantle & $-15.7--23.6$ & $0.2--6.8$ & Trask \& Van Dover, 1999 \\
\hline & Eiffel Tower vent & Gill & $-28.7--33.4$ & $-8.9--14.5$ & Trask \& Van Dover, 1999 \\
\hline & & Mantle & $-28.9--32.9$ & $-7.5--13.1$ & Trask \& Van Dover, 1999 \\
\hline Bathymodiolus azoricus & Menez Gwen & Fatty acids & $-24.9--34.9$ & & Pond et al., 1998 \\
\hline \multirow{5}{*}{ Bathymodiolus azoricus } & Rainbow close to vent & Gill & $-24.5--29.0$ & & Lein et al. (in press) \\
\hline & & Foot & $-22.4--22.6$ & & Lein et al. (in press) \\
\hline & Rainbow diffuse flow & Gill & $-22.0--26.1$ & & Lein et al. (in press) \\
\hline & Rainbow no flow & Gill & -22.6 & & Lein et al. (in press) \\
\hline & & Foot & -18.4 & & Lein et al. (in press) \\
\hline
\end{tabular}

\section{$C: \mathcal{N}:$ S ratio}

The vesicomyid gill contained $38.5 \%$ carbon, $9.5 \%$ nitrogen and $3.1-3.2 \%$ sulphur (dry weight); the vesicomyid foot contained $38.6 \%$ carbon, $10.9 \%$ nitrogen and $0.9-1.1 \%$ sulphur. The amount of sulphur in the gill is therefore about $3 \times$ that in the foot, and this adds to the evidence of the whitish colour of the gill filaments indicating elemental sulphur associated with the symbionts. The dried samples of the mussel and thyasirid were insufficient for elemental analysis.

\section{DISCUSSION}

Bathymodiolus puteoserpentis from the Snake Pit hydrothermal site is known to have two types of bacteria in the gills: the larger $\sim 1.5-2.0 \mu \mathrm{m}$ in diameter, containing stacks of intracytoplasmic membranes, the smaller $\sim 0.5 \mu \mathrm{m}$ in diameter (Cavanaugh et al., 1992). The two types of bacteria in the Logatchev Bathymodiolus are similar to those from Snake Pit in size and fine structure, but the large type is particularly abundant in the Logatchev mussel (numerically $\sim 50 \%$ in a transverse section of gill filament). The two bacterial morphotypes in the Snake Pit mussels are phylogenetically distinct, according to 16s rDNA sequence analysis and in situ hybridization, one species being related to a thiotroph and the other to a methanotroph (Distel et al., 1995).

Methanol dehydrogenase activity has been demonstrated in the Snake Pit mussel gills (Cavanaugh et al., 1992) and so has ${ }^{14} \mathrm{C}$-methane utilization (Robinson et al., 1998). The $\mathrm{CO}_{2}$-fixing enzyme RubisCo was also detected by Robinson et al. (1998), but in their experiments $\mathrm{CO}_{2}$ fixation was not stimulated by sulphide or thiosulphate, so the suspected co-existence of thiotrophy and methanotrophy could not be confirmed. The Snake Pit mussels analysed by Cavanaugh et al. (1992) and Robinson et al. (1998) had stable isotope ratios ranging from $\delta^{13} \mathrm{C}-34.2$ to $-37.6 \%$ and $\delta^{15} \mathrm{~N}$ ranging from -14.8 to $-19.3 \%$ (Table 2). The authors noted that the stable carbon isotope values were within the range for other thioautotrophic-bivalve symbioses and could therefore reflect carbon fixation via RubisCo, but without knowledge of the values for vent-derived methane it was not clear whether the mussels relied mainly upon methanotrophy or chemoautotrophy.

The very different value for the Logatchev mussel $\left(\delta^{13} \mathrm{C}\right.$ $-14.3,-14.6 \%$ o $)$ is out of the range for thiotrophic symbioses and compatible with the use of abiogenic methane. Logatchev hydrothermal methane, sampled at the Main mound, $\sim 250 \mathrm{~m}$ away from Anya's Garden, has ${ }^{13} \mathrm{C}-14.3 \%$ (Lein \& Sagalevich, 2000). This value is the same as that for the mussel, so the isotope data and fine structure both suggest that the Logatchev specimen was reliant chiefly on methanotrophic bacteria. It appears that the methane concentration in the main vent fluid at Logatchev is considerably higher than at most other vent areas on the MAR and about equal to that at Rainbow (Lein et al., 2001), but we have no measurements for the diffuse sources.

It is not possible to determine how much nourishment these mussels obtain by filter-feeding on suspended bacteria, but they probably obtain some, as uptake of carbon by filter feeding has been demonstrated in a coldseep Bathymodiolus species that has methanotrophic symbionts (Page et al., 1990; Pile \& Young, 1999). At $3000 \mathrm{~m}$ depth at Logatchev the organic material in suspension is likely to consist mainly of methanotrophic and thiotrophic bacteria, whose stable isotope signatures would be similar to those of the symbionts.

It is not unprecedented to find different stable isotope ratios in one species of vent mussel. Bathymodiolus azoricus at Lucky Strike shows a remarkable difference between populations taken from two areas of venting only a few hundred metres apart but fed by different hydrothermal fluid systems (Trask \& Van Dover, 1999). This difference was demonstrated for both $\delta^{13} \mathrm{C}$ and $\delta^{15} \mathrm{~N}$ (Table 2) and was attributed by Trask \& Van Dover to predominance of thiotrophy at one particular vent (Sintra), where the ${ }^{13} \mathrm{C}$ was more depleted (mean $\delta^{13} \mathrm{C}-31.1 \%$ ), and predominance of methanotrophy at Eiffel Tower vent $\left(\right.$ mean $\delta^{13} \mathrm{C}$ $-22.0 \%$ ). Lein et al. (2001) found a smaller range of $\delta^{13} \mathrm{C}$ values in $B$. azoricus living in a variety of habitats at Rainbow (Table 2), where the hydrothermal methane has a $\delta^{13} \mathrm{C}$ of $-13.4 \%$. Pond et al. (1998), working with fatty acids extracted from B. azoricus from Menez Gwen 
(Table 2), found stable carbon isotope values in the same range as the tissue values for Eiffel Tower specimens. They concluded from their analyses that thiotrophs and methanotrophs contributed equally to the nutrition of their mussel specimens. Among Bathymodiolus species living at hydrocarbon seeps in the Gulf of Mexico there appear to be two with dual symbionts and one with methanotrophs alone (reviewed by Gustafson et al., 1998). Many Bathymodiolus species from hydrothermal vents in the Pacific Ocean have only thiotrophs (Fisher et al., 1994; Nelson et al., 1995; Dubilier et al., 1998), but two have methanotrophs alone and these species live in hydrothermal vent areas where the concentration of methane is unusually high (Fujiwara et al., 2000).

The difference in nitrogen isotope ratios between Snake Pit (Table 2) and Logatchev examples of B. puteoserpentis (Table 1) may be compared with the corresponding values for Lucky Strike mussels at Sintra and Eiffel Tower (Table 2), suggesting a consistent difference in nitrogen metabolism between thiotrophic and methanotrophic symbionts. However, our values are still within the wide range reported for other symbiotrophic mussels, $\delta^{15} \mathrm{~N}-12.9-3.0 \%$ (Brooks et al., 1987; Fisher, 1995). Ammonium assimilation and dissimilatory nitrate reduction have been detected in seep mussel methanotrophic symbionts (Lee \& Childress, 1996), and the mussel gills have been shown to take up ammonium and dissolved amino acids (Lee et al., 1992). Choice of nitrogen source may depend on local availability as much as autotrophic mechanisms.

The vescomyid clams at Logatchev have only small coccoid bacteria as gill symbionts and they are very depleted in ${ }^{13} \mathrm{C}$ compared with the Bathymodiolus from the same habitat (Table 1). The cream colour in the gill indicates the presence of free sulphur, and there is $3 \times$ as much sulphur in the gill as in the foot, supporting the evidence from the stable isotope value that the symbionts are thiotrophs (Vetter \& Fry, 1998). The single demibranchs distinguish the Logatchev vesicomyid from the apparently usual condition of two demibranchs (e.g. Calyptogena magnifica Boss \& Turner 1980, C. pacifica and C. kilmeri Bernard 1974, C. phaseoliformis and C. laubieri Fiala-Médioni \& Le Pennec, 1988, and Ectenagena extenta Krylova \& Moskalev, 1996). The multicylindrical organization of the subfilamentar region of the gill filaments is unexpected for a vesicomyid. It resembles the situation in some symbiontcontaining species of Lucinidae, for which it has been suggested that the structure may improve control of sulphide and oxygen levels in the bacteriocytes and the blood (Distel \& Felbeck, 1987; Frenkiel et al., 1996). The grouping of bacteria in closed vacuoles is typical of vesicomyids in general.

The thyasirid is the least studied of the three bivalves from Logatchev. The material was not very well preserved, but the gill sections show large numbers of bacteria in superficial blisters, supported by long microvilli, and covered by microvillar tips, as found in the shallow-water thyasirids Thyasira sarsi and T. flexuosa. These are dependent on thiotrophic symbionts (Dando \& A.J. Southward, 1986; E.C. Southward, 1986). The Logatchev thyasirid has only one type of symbiont, unlike two deep-water species of thyasirid from the Bay of Biscay which have a mixture of two types of symbiont, neither apparently methanotrophic
(Southward, 1986). Both the thyasirid and the vesicomyid are strongly depleted in ${ }^{13} \mathrm{C}$, indicating similar thiotrophic activities and $\mathrm{CO}_{2}$ sources, but the nitrogen isotope values, negative in the thyasirid and positive in the vesicomyid (Table 1), may indicate some difference in their nitrogen sources, related to the animals' depth in the sediment.

The three bivalve species, collected within $2 \mathrm{~m}$ of one another, from a fairly small area of grey-black sediment, lived in slightly different positions. The mussels were on the surface, attached to hard objects in places where there was visible, shimmering flow. The vesicomyids were partly buried, with the foot able to probe into the sulphidic sediment, while the thyasirids were probably more deeply buried, though their dead shells were visible on the surface. Thyasirids typically bury themselves at least five shell-lengths down, ventilating their mantle cavities via inhalent and exhalent channels they build and maintain with their foot. Thus the mussels would have access to hydrothermal methane, whereas the vesicomyids and thyasirids could obtain reduced sulphur compounds in the sediment. Though the species' individual behaviour is just as would be expected, this is the first time that such an assemblage has been found at a hydrothermal site on the MAR, with the different faunistic elements exploiting different energy resources.

The submersible work at sea in 1997 and the laboratory studies, were supported by the UK Natural Environment Research Council (NERG), through the UK BRIDGE programme (grant GST/02/1478). H.K. was supported by NERC grant JREI (GR3 E0068). We are indebted to Professor J.R. Cann, FRS, Professor P.A. Tyler, Dr D. Fornari and Dr K. Harrison for arranging our participation in the MAR '97 cruise of RV 'Atlantis' and we thank Professor R.C. Vrijenhoek and Professor R.A. Lutz for their willingness to share the third leg of the cruise. The 'Alvin' team kindly gave us every assistance. We thank R.N. Head for the elemental analysis and Elena Krylova for advice about the vesicomyid and thyasirid bivalves.

\section{REFERENCES}

Bernard, F.R., 1974. The genus Calyptogena in British Columbia with a description of a new species. Venus, 33, 11-22.

Boss, K.J. \& Turner, R.D., 1980. The giant white clam from the Galapagos Rift. Calyptogena magnifica species novum. Malacologia, 20, 185-190.

Brooks, J.M., Kennicutt, M.C., Fisher, C.R., Macko, S.A., Cole, K., Childress, J.J., Bidigare, R.R. \& Vetter, R.D., 1987. Deep-sea hydrocarbon seep communities: evidence for energy and nutritional carbon sources. Science, New York, 238, $1138-1142$.

Cavanaugh, G.M., Wirsen, C.O. \& Jannasch, H.W., 1992. Evidence for methylotrophic symbionts in a hydrothermal vent mussel (Bivalvia: Mytilidae) from the Mid-Atlantic Ridge). Applied and Environmental Microbiology, 58, 3799-3803.

Cosel, R. von, Comtet, T. \& Krylova, E., 1999. Bathymodiolus (Bivalvia: Mytilidae) from hydrothermal vents on the Azores Triple Junction and the Logatchev hydrothermal field, MidAtlantic Ridge. The Veliger, 42, 218-248.

Cosel, R. von, Métivier, B. \& Hashimoto, J., 1994. Three new species of Bathymodiolus (Bivalvia: Mytilidae) from hydrothermal vents in the Lau Basin and the Fiji Basin, western Pacific, and the Snake Pit area, Mid-Atlantic Ridge. The Veliger, 37, 374-392. 
Craddock, C., Hoeh, W.R., Gustafson, R.G., Lutz, R.A., Hashimoto. J. \& Vrijenhoek, R.C., 1995. Evolutionary relationships among deep-sea mytilids (Bivalvia: Mytilidae) from hydrothermal vents and cold-water methane/sulfide seeps. Marine Biology, 121, 477-485.

Dando, P.R. \& Southward, A.J., 1986. Chemoautotrophy in bivalve molluscs of the genus Thyasira. Fournal of the Marine Biological Association of the United Kingdom, 66, 915-929.

Distel, D.L. \& Felbeck, H., 1987. Endosymbiosis in the lucinid clams Lucinoma aequizonata, Lucinoma annulata and Lucina floridana: a reexamination of the functional morphology of the gills as bacteria-bearing organs. Marine Biology, 96, 79-86.

Distel, D.L., Lee, H.K.-W. \& Cavanaugh, C.M., 1995. Intracellular coexistence of methano- and thioautotrophic bacteria in a hydrothermal vent mussel. Proceedings of the National Academy of Sciences of the United States of America, 92, 9598-9602.

Dubilier, N., Windoffer, R. \& Giere, O., 1998. Ultrastructure and stable carbon isotope composition of the hydrothermal vent mussels Bathymodiolus brevior and B. sp. affinis brevior from the North Fiji Basin, western Pacific. Marine Ecology Progress Series, 165, 187-193.

Fiala-Médioni, A. \& Le Pennec, M., 1988. Structural adaptations in the gill of the Japanese subduction zone bivalves (Vesicomyidae) Calyptogena phaseoliformis and Calyptogena laubieri. Oceanologica Acta, 11, 185-192.

Fiala-Médioni, A. \& Métivier, C., 1986. Ultrastructure of the gill of the hydrothermal vent bivalve Calyptogena magnifica, with a discussion of its nutrition. Marine Biology, 90, 215-222.

Fisher, C.R., 1995. Toward an appreciation of hydrothermal-vent animals: their environment, physiological ecology, and tissue stable isotope values. Geophysical Monographs, 91, 297-316.

Fisher, C.R., Childress, J.J., Brooks, J.M. \& Macko, S.A., 1994. Nutritional interactions in Galapagos Rift hydrothermal vent communities: inferences from stable carbon and nitrogen isotope analyses. Marine Ecology Progress Series, 103, 45-55.

Frenkiel, L., Gros, O. \& Mouëza, M., 1996. Gill structure in Lucina pectinata (Bivalvia: Lucinidae) with reference to hemoglobin in bivalves with symbiotic sulphur-oxidizing bacteria. Marine Biology, 125, 511-524.

Fujiwara, Y., Takai, K., Uematsu, K., Tsuchida, S., Hunt, J.C. \& Hashimoto, J., 2000. Phylogenetic characterization of endosymbionts in three hydrothermal vent mussels: influence on host distributions. Marine Ecology Progress Series, 208, 147-155.

Gebruk, A.V., Chevaldonné, P., Shank, T., Vrijenhoek, R.C. \& Lutz, R.A., 2000a. Deep-sea hydrothermal vent communities of the Logatchev area $\left(14^{\circ} 45^{\prime} \mathrm{N}\right.$, Mid-Atlantic Ridge): diverse biotopes and high biomass. Fournal of the Marine Biological Association of the United Kingdom, 80, 383-393.

Gebruk, A.V., Southward, E.C., Kennedy, H. \& Southward, A.J., 2000b. Food sources, behaviour, and distribution of hydrothermal vent shrimps at the Mid-Atlantic Ridge. Fournal of the Marine Biological Association of the United Kingdom, 80, 485-499.

Gustafson, R.G., Turner, R.D., Lutz, R.A. \& Vrijenhoek, R.C., 1998. A new genus and five new species of mussels (Bivalvia, Mytilidae) from deep-sea sulfide/hydrocarbon seeps in the Gulf of Mexico. Malacologia, 40, 63-12.

Jollivet, D., Comtet, T., Chevaldonné, P., Hourdez, S., Desbruyères, D. \& Dixon, D.R., 1998. Unexpected relationship between dispersal strategies and speciation within the association Bathymodiolus (Bivalvia) - Branchipolynoe (Polychaeta) inferred from the rDNA neutral ITS2 marker. Cahiers de Biologie Marine, 39, 359-362.

Krylova, H.M. \& Moskalev, L.I., 1996. Ectenagena extenta, a new species of vesicomyid bivalve from Monterey Bay, California. Ruthenica, 6, 1-10.
Lee, R.W. \& Childress, J.J., 1996. Inorganic N assimilation and ammonium pools in a deep-sea mussel containing methanotrophic endosymbionts. Biological Bulletin, Marine Biological Laboratory, Woods Hole, 190, 373-384.

Lee, R.W., Thuesen, E.V., Childress, J.J. \& Fisher, C.R., 1992. Ammonium and free amino acid uptake by a deep-sea mussel (Bathymodiolus sp., undescribed) containing methanotrophic bacterial symbionts. Marine Biology, 113, 99-106.

Lein, A.Y., Pimenov, N.V., Gebruk, A.V., Moskalev, L.I., Bagirov, N.E. \& Ivanov, M.V., 2001. Trophic structure and composition of the Rainbow hydrothermal community $\left(36^{\circ} \mathrm{N}\right.$, MidAtlantic Ridge). Doklady Rossiskoy Akademii Nauk, 376, 120-123. [In Russian.]

Lein, A.Y. \& Sagalevich, A.M., 2000. Smokers of the Rainbow field - an area of a large abiogenic methane synthesis. Priroda, 8, 44-53. [In Russian.]

Le Pennec, M. \& Hily, A., 1984. Anatomie, structure et ultrastructure de la branchie d'un Mytilidae des sites hydrothermaux du Pacifique oriental. Oceanologica Acta, 7, 517-523.

Maas, P.A.Y., O’Mullen, G.D., Lutz, R.A. \& Vrijenhoek, R.C., 1999. Genetic and morphometric characterization of mussels (Bivalvia: Mytilidae) from Mid-Atlantic Ridge hydrothermal vents. Biological Bulletin, Marine Biological Laboratory, Woods Hole, 196, 265-272.

Nelson, D.C., Hagen, K.D. \& Edwards, D.B., 1995. The gill symbiont of the hydrothermal vent mussel Bathymodiolus thermophilus is a psychrophilic, chemoautotrophic, sulfur bacterium. Marine Biology, 121, 487-495.

Page, H.M., Fisher, C.R. \& Childress, J.J., 1990. Role of filterfeeding in the nutritional biology of a deep-sea mussel with methanotrophic symbionts. Marine Biology, 104, 251-257.

Pile, A.J. \& Young, C.M., 1999. Plankton availability and retention efficiencies of cold-seep symbiotic mussels. Limnology and Oceanography, 44, 1833-1839.

Pond, D.W., Bell, M.V., Dixon, D.R., Fallick, A.E., Segonzac, M. \& Sargent, J.R., 1998. Stable-carbon-isotope composition of fatty acids in hydrothermal vent mussels containing methanotrophic and thiotrophic bacterial endosymbionts. Applied and Environmental Microbiology, 64, 370-375.

Robinson, J.J., Polz, M.F., Fiala-Médioni, A. \& Cavanaugh, C.M., 1998. Physiological and immunological evidence for two distinct $\mathrm{C}_{1}$-utilizing pathways in Bathymodiolus puteoserpentis (Bivalvia: Mytilidae), a dual endosymbiotic mussel from the Mid-Atlantic Ridge. Marine Biology, 132, 625-633.

Rona, P., Klinkhammer, G., Nelsen, T.A., Trefry, J.H. \& Elderfield, H., 1986. Black smokers, massive sulphides and biota at the Mid-Atlantic Ridge. Nature, London, 312, 33-37.

Segonzac, M., 1992. Les peuplements associés à l'hydrothermalisme océanique du Snake Pit (dorsale médio-atlantique; $23^{\circ} \mathrm{N}$, $3480 \mathrm{~m}$ ): composition et microdistribution de la mégafaune. Comptes Rendus de l'Académie des Sciences de Paris, Sér. III, 314, 593-600.

Southward, E.C., 1986. Gill symbionts in thyasirids and other bivalve molluscs. Fournal of the Marine Biological Association of the United Kingdom, 66, 889-914.

Trask, J.L. \& Van Dover, C.L., 1999. Site-specific and ontogenetic variations in nutrition of mussels (Bathymodiolus sp.) from the Lucky Strike hydrothermal vent field, Mid-Atlantic Ridge. Limnology and Oceanography, 44, 334-343.

Tuttle, J.H., 1985. The role of sulfur-oxidizing bacteria at deepsea hydrothermal vents. Bulletin of the Biological Society of Washington, 6, 335-343.

Vetter, R.D. \& Fry, B., 1998. Sulfur contents and sulfur-isotope compositions of thiotrophic symbioses in bivalve molluscs and vestimentiferan worms. Marine Biology, 132, 453-460.

Submitted 3 November 2000. Accepted 11 May 2001. 